\title{
A conceptual framework to measure operational efficiency of Apparel Industry in emerging economies
}

\begin{abstract}
Operational efficiency means the organization's ability to decrease wastage of inputs and maximize resource utilization. This could be done by increasing supply quality and eliminating the low-quality products and services for customers (González \& Álvarez, 2001. Operational efficiency is a useful measure which utilizes the available resources (González \& Álvarez, 2001). In this study, researcher was able to develop a more consice conceptual framework which can be used to measure the operational efficiency of Apparel industry in emerging economies. This conceptual framework is based on an extensive literature review with fifty (50) research articles which discussed on the operational efficiency in Apparel industry of emerging economies. Four different databases have been used to access the research articles in developing this conceptual framework. These are Sage, Google Scholar, Scopus and Pro Quest. This conceptual framework consist of five independent variables which are labor productivity, inventory management, technology, organizations management, supply chain management and dependent variable is operational efficiency.
\end{abstract}

Keywords: operational efficiency, apparel industry, emerging economies, conceptual framework

\section{Introduction}

The demand for the apparel industry increases with the growth of global population. Even though apparel production increases over time, the rate of increase is not sufficient to fulfil the increasing demand. There is a high demand for apparel industry as it has a great potential to contribute economies of countries which produce apparels. Operational efficiency is driven by operational factors such as human resource management, supply chain management, quality control management, technology etc. Moreover, customer satisfaction and public perception is also important as identified by Slack (2015). To achieve operational efficiency Jacobs, Chase, and Lummus (2014) mentioned that all data of an organization must collect, record and analyse to 
define the extent of probability. Operations consist of supply chain management, marketing, finance and human resource management (Staiger, 2017). The operations function needs administration of the production of goods and services. The handling, manufacturing or service processes comprise of operations strategy, product design, process design, quality management, capacity and facility planning (Sayer et al., 2013). Each of these process's needs an ability to examine the present state and discover superior explanations to advance the efficiency and effectiveness of the workshop or service procedures (Gaither \& Frazier, 2002).

According to Tuuli and Rowlinson (2010), “operations management is a part of administration distracted with the planning and monitoring protocols which makes and reforms commercial operations in the manufacture of goods or services." Operations are one of the main tasks comprises with the supply chains, marketing, finance and human resources as identified by Staiger (2017). The identification of the manufacturers' competitive advantages are highly important in the manufacturing research studies. However, there are relatively limited studies which measured the constructs in published research (Cheng, Goh, \& Kim, 2017). In operations management research it is evident that few studies focus on individual corporate decisions, inventory management and supply chain management (Cheng et al., 2017; Feng, Li, McVay, \& Skaife, 2014). A production structure consist of a procedure that transforms inputs (in the procedures of raw materials, labor, and energy) into outputs (in the method of goods and/or services) (Hugos, 2018).

According to the Okwang'a, Mungania, and Karanja (2015) findings revealed that management factors such as leadership, planning and organizing are essential in achieving operational efficiency in the apparel industries. Other factors include communication, financial resource availability, employing other factors that affect operational efficiency and in retaining committed employees (Okwang'a et al., 2015). The research further revealed that most of the apparel industries do not operate efficiently because they are ignorant of the factors that affect operational efficiency and also they do not have financial resources that are necessary in employing these resources (Keiser, Garner, \& Vandermar, 2017). Yadlapalli, Rahman, and Gunasekaran (2018) conceptualized supplier selection and supplier development as the governance mechanisms of social responsibility. This study tested the hypothesized relationship of socially responsible 
governance mechanisms and firm performance and revealed that both supplier-selection and supplier-development governance mechanisms have a positive effect on a firm's social and environmental performance in the Bangladesh apparel sector (Yadlapalli et al., 2018).

\section{Literature Review}

This study engaged with an extensive literature review using fifty (50) research articles. This section covers various scholarly studies on operational efficiency in Apparel sector of emerging economies.

\subsection{Apparel Industry in emerging economies}

Apparel sector in emerging economies are a major export. The demand is increasing as apparels are basic needs of the people and with the growth of the global population. Even though apparel production increases over time the rate of increment is not sufficient to fulfil the increasing demand )Embuldeniya, 2015). World Trade Organization phase-out of the quota system for textiles and apparel in 2005, which provided access for many poor and small export-oriented economies to the markets of industrialized countries (Gereffi \& Frederick, 2010). The current economic recession lowered demand for apparel exports led to massive unemployment in the emerging economies (Gereffi \& Frederick, 2010).

The China, Bangladesh, India and Vietnam can be considered as some of the major giants in this sector (Gereffi \& Frederick, 2010). For most of the emerging economies, apparel sector is the primary stepping stone for industrialization (Kim, Traore, \& Warfield, 2006). Due to lack of entry barriers and high wage rates, majority of the developed countries import apparel products from emerging economies (Kim et al., 2006). The textile and apparel complex is one of the most labor-intensive industry out of all other manufacturing industries (Kim et al., 2006). The below Figure 1 illustrates the share of the world apparel exports and Apparel's share of total exports based on the World Bank Statistics in 2016 to 2017. 
Figure 1: Share of the world apparel exports 2016/2017

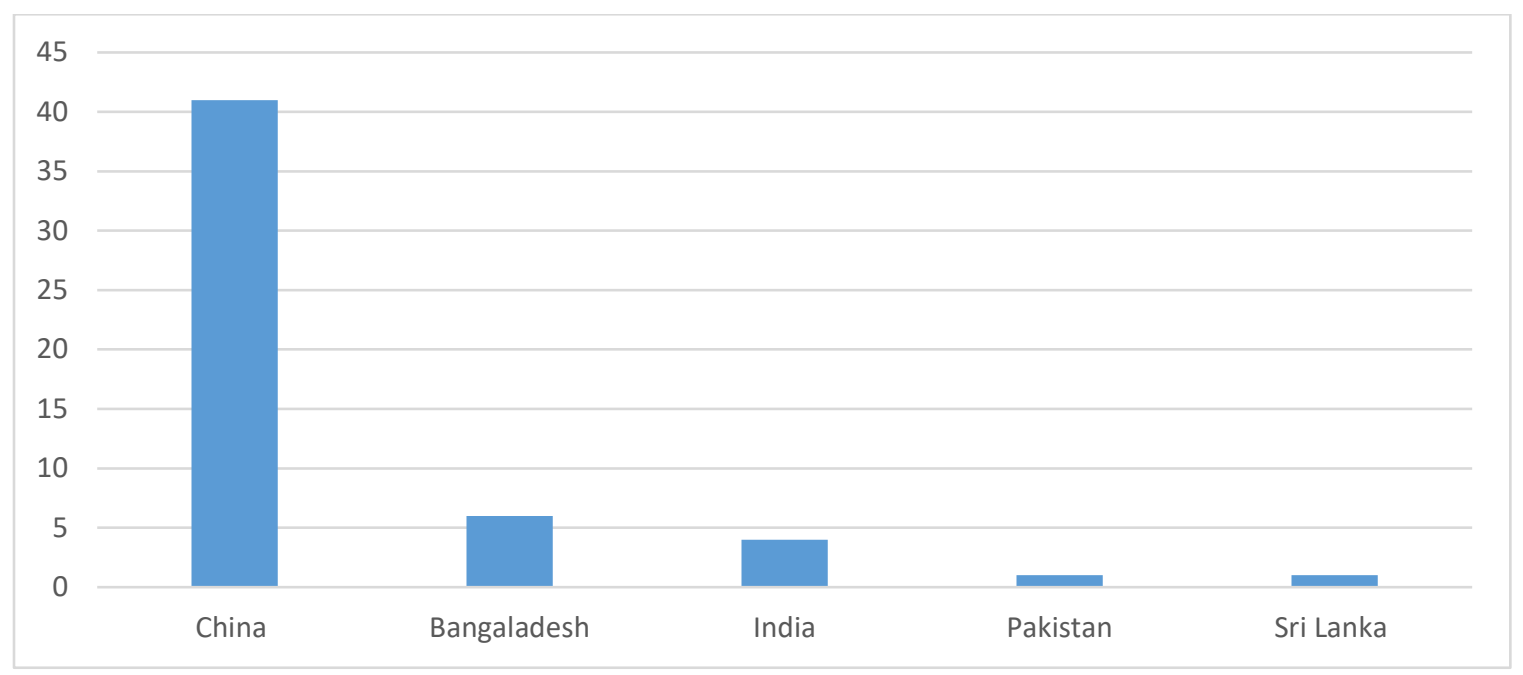

Source: Based on the World Bank Statistics of year 2016/2017

\subsection{Importance of operational efficiency}

The term "efficiency" is common for industrial organizations due to firm-specific factors of management skills, innovation, cost control and market share as determinants of current firm performance and its stability (Kalluru \& Bhat, 2009). Operational efficiency is the proficiency of a corporation to limit and maximize resource capabilities which deliver quality products and services to customers (Kalluru \& Bhat, 2009).

Improving operational efficiency has a direct impact on the organizations profit margins and efficient firms are more cost-effective. The operational efficiency is vital for any type of business and considered by senior management to earn a healthy and sustainable financial performances (Sufian, 2007). Operational efficiency is often achieved by streamlining the organisations core procedures. This contributes to respond efficiently to continually changing market forces in a cost effective way (Barnett \& Burgelman, 1996). Therefore, it is vital to increase the international market share for any firm to be competitive in the international market. It is highly essential for business organisations to improve their operational efficiency when possible. Thus, any business organization not using effective operational practices experience financial drawbacks (Slack, Brandon-Jones, \& Johnston, 2013). 
According to Jacobs et al, (2014), "operational efficiency is about the output to input proportion, it needs to be calculated on with the input and output values." Other studies focus on operational efficiency in the prior research which conducted on effective internal control measurements are; (Dhaliwal, Hogan, Trezevant, \& Wilkins, 2011; Feng et al., 2014). It is hypothesise that ineffective internal controls has a negative effect on firm operational efficiency. The ineffective internal control can result in inaccurate internal management reports (Feng et al., 2014). To achieve operational efficiency Jacobs et al. (2014) an organization must collect, record and analysis data to define the extent of probability. Operational efficiency is the key determinant for long-term solvency for any business, in fact, firm-specific determinants of financial performance involve operating efficiency and financial risk. Some of the major studies are summarized in Table 1 as below.

\section{Table 1: summarizes the studies of operational efficiency in Apparel sector}

\begin{tabular}{|l|l|l|l|}
\hline Year & Author & Findings \\
\hline 01 & 2002 & $\begin{array}{l}\text { Moore, } \\
\text { Marguerite }\end{array}$ & $\begin{array}{l}\text { Study is based on retailer profitability in the USA apparel retailing } \\
\text { sector. This study examined the impact of different strategies on } \\
\text { organizations performance. Specifically, operational efficiency, } \\
\text { marketing effectiveness and innovation are examined by identifying its } \\
\text { influence on operational and financial performance. Findings suggest } \\
\text { that operational efficiency and marketing effectiveness as well as } \\
\text { innovation has a positive influence on performance of the domestic } \\
\text { retail industry. This study consist of the implications which are suitable } \\
\text { for theory and practice (Moore, 2002) }\end{array}$ \\
\hline 02 & 2001 & $\begin{array}{l}\text { Deraniyagala, } \\
\text { Sonali }\end{array}$ & $\begin{array}{l}\text { Study examined the effects of technology accumulation on firm-level } \\
\text { technical efficiency in the Sri Lankan clothing and agricultural } \\
\text { machinery industries, using cross-section survey data. The analysis } \\
\text { shows simple adaptive technical change to have a significant and } \\
\text { positive effect on efficiency in both industries. In addition, variables } \\
\text { relating to technological skills and training also emerge as significant } \\
\text { determinants of firm-level efficiency (Deraniyagala, 2001) }\end{array}$ \\
\hline 03 & 2010 & $\begin{array}{l}\text { Joshi, RN } \\
\text { Singh, SP }\end{array}$ & $\begin{array}{l}\text { Study is about the indian apparel sector. Main findings indicated } \\
\text { that the small-scale firms are found to be more productive than the }\end{array}$ \\
\hline
\end{tabular}




\begin{tabular}{|c|c|c|c|}
\hline & & & $\begin{array}{l}\text { medium- and large-scale firms. The decomposition of apparel } \\
\text { industry growth into technical efficiency change (catch-up effect) } \\
\text { and technological change (frontier shift) reveals that the } \\
\text { productivity growth is contributed largely by technical efficiency } \\
\text { change rather than by technological change (Joshi \& Singh, 2010) }\end{array}$ \\
\hline 04 & 2006 & Scott, Allen J & $\begin{array}{l}\text { Study is based on geographic investigation of low-technology, labor- } \\
\text { intensive industries which are on invoking notions of industrial } \\
\text { organization, locational agglomeration, and spatial divisions of labor. } \\
\text { The distribution of the clothing, footwear, and furniture industries } \\
\text { across the contemporary world is described on the basis of detailed } \\
\text { published statistics. This also examined international flows of finished } \\
\text { products and production-sharing activities involving various kinds of } \\
\text { subcontracting arrangements between high-wage and low-wage } \\
\text { countries. The significance of low-wage, low-technology industries for } \\
\text { processes of economic development is also investigated by this study } \\
\text { (Scott, 2006) }\end{array}$ \\
\hline 05 & 2002 & $\begin{array}{l}\text { Moodley, } \\
\text { Sagren }\end{array}$ & $\begin{array}{l}\text { Study discussed the role of e-business with special reference to } \\
\text { connecting to markets, productivity gains, potential cost savings, and } \\
\text { systemic efficiencies. The empirical evidence suggested that e- } \\
\text { business in the garments industry is in its infancy. The South African } \\
\text { apparel industry is at a critical stage in its development after a declining } \\
\text { period. This also argued that the clothing sector's importance on job } \\
\text { creation, and foreign exchange earnings for South Africa which } \\
\text { depends on how well policymakers and industrialists understand the } \\
\text { forces shaping the market and are prepared to move fast to create the } \\
\text { necessary conditions for a coordinated fast track lift-off (Moodley, } \\
2002 \text { ) }\end{array}$ \\
\hline 06 & 1998 & $\begin{array}{l}\text { Ramaswamy, } \\
\text { KV } \\
\text { Gereffi, Gary }\end{array}$ & $\begin{array}{l}\text { The discussion of this study is on the apparel sector of India and } \\
\text { focused on three themes: First, the interlinkages in the organisation of } \\
\text { international economic activity and the changing competitive } \\
\text { conditions in the global apparel market; second, the associated } \\
\text { importance of distribution and marketing links in the apparel } \\
\text { production chain; and third, the cotton fabric- based nature of India's }\end{array}$ \\
\hline
\end{tabular}




\begin{tabular}{|c|c|c|c|}
\hline & & & $\begin{array}{l}\text { apparel exports and its competitive advantage (Ramaswamy \& Gereffi, } \\
\text { 1998). }\end{array}$ \\
\hline 07 & 1999 & $\begin{array}{l}\text { Bhattacharya, } \\
\text { Debapriya } \\
\text { Rahman, } \\
\text { Mustafizur }\end{array}$ & $\begin{array}{l}\text { Study focused about the women entering the industrial labour force in } \\
\text { Bangladesh generally find themselves in low skill/low wage jobs with } \\
\text { special reference to apparel sector. Nevertheless, increasing } \\
\text { liberalization of the global textiles market creates new challenges for } \\
\text { countries and industries that rely on a low skill/low wage strategy. } \\
\text { They eventually find it difficult to increase productivity, and thus to } \\
\text { retain their place in increasingly competitive markets. A second } \\
\text { incentive for change is provided by the phasing out of the Multi-Fiber } \\
\text { Arrangement, which limited inputs of domestic origin in clothing } \\
\text { production. In the current situation, Bangladesh has a unique } \\
\text { opportunity to restructure its domestic apparel sector, introducing new } \\
\text { technologies and fostering domestic production linkages. Findings } \\
\text { indicated the public sector allocations combined with private sector } \\
\text { training of the female labour force, which can stimulate women's } \\
\text { engagement in the apparel sector, raise their productivity and } \\
\text { ultimately improve their livelihoods (Bhattacharya \& Rahman, 1999). }\end{array}$ \\
\hline 08 & 2004 & $\begin{array}{l}\text { Fernie, John } \\
\text { Azuma, } \\
\text { Nobukazu }\end{array}$ & $\begin{array}{l}\text { This paper explored the future direction of fashion in the } \\
\text { industrialized economies through the experience of the Japanese } \\
\text { fashion industry from a small manufacturers' perspective. } \\
\text { Empirical findings from a questionnaire survey revealed the } \\
\text { fundamental gaps that exist between the theory and the practice. } \\
\text { Several survival strategies been introduced in this study for } \\
\text { domestic apparel manufacturing in the industrial economies } \\
\text { (Fernie \& Azuma, 2004) }\end{array}$ \\
\hline 09 & 2009 & $\begin{array}{l}\text { Miller, Doug } \\
\text { Williams, Peter }\end{array}$ & $\begin{array}{l}\text { This article examined the ways in which a living wage might be } \\
\text { implemented in the global apparel sector. This also argued that an } \\
\text { increase in the unit labour cost element of the free on board price paid } \\
\text { by brands by a factor equivalent to the difference between the } \\
\text { existing wage and a nationally determined living wage figure would } \\
\text { not impact in any serious way upon retailer or brand-owner's (or } \\
\text { supplier's) bottom line. The existence of fragmented and outsourced } \\
\text { manufacturing, accompanied by aggressive buying practices, }\end{array}$ \\
\hline
\end{tabular}




\begin{tabular}{|c|c|c|c|}
\hline & & & $\begin{array}{l}\text { militates against 'aspirational' code provisions in this area. Limited } \\
\text { progress is possible only through substantial brand collaboration, an } \\
\text { acceptance of collective bargaining through trade unions in supplier } \\
\text { factories and, longer term, moves by brands and retailers to own and } \\
\text { control their own manufacturing capacity (Miller \& Williams, 2009). }\end{array}$ \\
\hline 10 & 2003 & $\begin{array}{l}\text { Moodley, } \\
\text { Sagren }\end{array}$ & $\begin{array}{l}\text { The paper suggests a raft of policy measures designed to create an } \\
\text { enabling and nurturing environment aimed at promoting and } \\
\text { accelerating the diffusion of B2B e-commerce technologies in the SA } \\
\text { apparel sector (Moodley, 2003). }\end{array}$ \\
\hline 11 & 2003 & $\begin{array}{l}\text { Roberts, Simon } \\
\text { Thoburn, John }\end{array}$ & $\begin{array}{l}\text { This paper examines the responses of firms in the textile industry of } \\
\text { South Africa to that country's rapid liberalization of trade since the } \\
\text { early 1990s. Findings indicated that increased exports accompanied } \\
\text { by reductions in employment and contraction of production of yarns } \\
\text { and fabrics. It also documented how competitive pressures from } \\
\text { imports have led firms to increase their exports. Firms focusing on } \\
\text { non-price factors of export competitiveness have been better } \\
\text { performing. Firms have also been most successful where } \\
\text { technological capabilities based on the domestic market provided a } \\
\text { foundation for export competitiveness (Roberts \& Thoburn, 2003). }\end{array}$ \\
\hline 12 & 2004 & $\begin{array}{l}\text { Moodley, } \\
\text { Sagren } \\
\text { Morris*, Mike }\end{array}$ & $\begin{array}{l}\text { Study focused on adoption of e-commerce applications is promoted in } \\
\text { the developing world as a systemic innovation offering producer firms } \\
\text { new exchange mechanisms that enable them to compete on a more } \\
\text { equal basis in world markets. Empirical evidence obtained from } \\
\text { researching leading garment exporting firms in South Africa suggests } \\
\text { that B2B e-commerce is not as effective in reducing transaction costs } \\
\text { or in opening up new global market opportunities as claimed by the } \\
\text { "optimists". It has only marginally altered trading and business } \\
\text { patterns between international buyers and sellers in the garment } \\
\text { industry. The findings indicate that trading relationships in this sector } \\
\text { are fostered over extended periods of time, depend on non-contract } \\
\text { based activities and on complex information requirements and tend to } \\
\text { be highly personalized (Moodley \& Morris*, 2004). }\end{array}$ \\
\hline
\end{tabular}

Source: Constructed by the author 


\subsection{Operational efficiency using data envelopment analysis (DEA) model}

A study conducted by Arunkumar and Ramanan (2017) mentioned that operational efficiency of the food and beverages industry in India is determined by identifying the technical and scale efficiencies by applying data envelopment analysis (DEA) models. The first stage DEA analysis revealed that the inefficiencies such as scale and technical inefficiencies exist in the Indian food and beverages industry and a majority of inefficient firms are operating in the increasing returns to scale region. Another fining of this study was that determinants of these inefficiencies are due to current ratio and financial assets to total assets rations which are contributing significantly to the inefficiencies (Arunkumar \& Ramanan, 2017). Similarly the operational efficiency is assessed in the hospitals using the data envelopment analysis (DEA) models and the results illustrated by comparing the solutions of complete data sets against the simulated versions of the same data sets with missing data. The sensitivity of each method on the efficiency scores and ranking of the decision-making units are presented (Aksezer \& Benneyan, 2010).

\section{Methodology}

The major objective of this paper is to develop a more consice conceptual framework which can be used to measure the operational efficiency of Apparel industry in emerging economies. This conceptual framework is developed using an extensive literature review by referring to fifty (50) research articles conduced on operational efficiency in Apparel industry in emerging economies. The primary data collection is through four different databases which have been used to access the research articles. These databases are Sage, Google Scholar, Scopus and Pro Quest. These databases were used in developing this conceptual framework. Additionally, researcher used other published books. The variables presented in the conceptual framework are based on the literature review. Therefore, the below five (5) variables analysed the specific phenomenon of the study. Consequently, conceptual framework comprised of only five independent variables which are labor productivity, inventory management, technology, management and culture, supply chain management. The below description is a justification of the following variables. Therefore, the most applicable research design for this paper is positivism or quantitative methodology. 
The proposed conceptual framework which is based on the evaluation of the literature review is illustrated in Figure 2 as below.

Figure 2: Proposed conceptual framework

\begin{tabular}{|l|l|}
\hline \multicolumn{1}{|c|}{ Independent Variables } & $\begin{array}{l}\text { Dependent Variables } \\
\text { Operational Efficiency in } \\
\text {-Labor productivity } \\
\text {-Inventory management } \\
\text {-Updated Technology } \\
\text {-Management and culture } \\
\text {-Supply chain management }\end{array}$ \\
\hline
\end{tabular}

Source: Constructed by the author

The above conceptual framework consists of five independent variables which are labor productivity, inventory management, technology, management and culture, supply chain management and the dependent variable is operational efficiency. These five variables are justified using the below literature review.

\subsection{Labor productivity}

For the service sector it is essential to have an exact method to measure the input and output ratios rendered by the workers. Productivity is well-defined as the ratio between the output volume and the input volume (Hulten, 2001). Workforce productivity is the amount of goods and services that a worker produces in a given amount of time. Out of all the factors of production labor hours are of highest priority and the most important factor of production and plays an essential role in parts of efficiency and superiority. He also stated that, "The concept of productivity is often measured differently. However, in a more subjective manner, by asking about the degree to which the work environment influences productivity" (Hulten, 2001).

The Organization for Economic Co-operation and Development (OECD) defines the work force productivity as "the ratio of a volume measure of output to a volume measure of input" (OECD, 2002).The concept of productivity is often measured differently, with the degree to which the work environment influences productivity in a more objective manner by using the number of hours or 
percentage of idle time (Bergs, 2002). A number of indicators provides as an indication to represent these factors. Similarly, Bergs (2002) uses; the quantity of work, quality of work, meeting deadlines, frequency of errors, responsibilities, creativity, interpersonal relations, as the main factors.

The main objective of human resources management is to utilize the human resources in a most optimal manner so that targets can be achieved very effectively and efficiently. For this purpose, managing performance of employees are vital. Therefore, the performance management maintains, develop and motivates the people at work to give better results. In the present competitive situation, the organization that gives better results can survive, stabilize, grow and excel in the performance. It helps a lot in achieving the objectives of "Human Resource Management." Performance management includes activities to ensure that goals are consistent effective and efficient. Performance management can focus on performance of the organization, a department, processes to build a product or service, employees, etc. (Kotler \& Armstrong, 2010).

H1: Labor productivity is positively related to operational efficiency

$\mathrm{H} 2$ : Labor productivity is negatively related to operational efficiency

\subsection{Inventory management}

According to Jarkas and Bitar (2011), "the objective of inventory management is to strike a balance between inventory investment and customer service." Therefore it is impossible to achieve a lowcost strategy without a proper inventory management system (Jarkas \& Bitar, 2011).Therefore (Stevenson \& Hojati, 2007) states that to accommodate the functions of the inventory, there are four main types of inventory as follows such as "Raw material inventory" which is the materials that are usually purchased hence in the working progress stage in the manufacturing process. This inventory can be used to decouple supplier from the production process.

However, the preferred approach is to eliminate supplier variability in quality, quantity, or delivery time so that separation is not necessary. Second, "Working in process (WIP) inventory" that are components or raw material should undertake some changes. WIP exists because of the time it takes for a product to be made (Cycle Time). Reducing cycle time reduces inventory. Third, "maintenance/repair/operating supply inventory" that are inventories devoted to maintenance/repair/operating inventory supplies are necessary to keep machinery and processes 
more productive. This type of inventory exist as the need and timing for maintenance and repairing for some equipment is unknown. Although the demand for MRO inventory is often a function of maintenance schedules, other unscheduled MRO demands must be anticipated. Finally, finished goods inventory is a completed product awaiting the shipment. Finished goods are inventories as future customer demands are unknown, but still an asset on the company financial statements. H3: Inventory management is positively related to operational efficiency

H4: Inventory management is negatively related to operational efficiency

\subsection{Updated Technology}

A company can produce goods or services that are widely available or internationally competitive using the technological progress made in a specialized field (Porter, 2000). Again, real and perceived benefits must be differentiated. Many companies believe they are the only products or services, even though this might not be the case in the international market. If products or technology are unique, however, company can positively offer a competitive edge and effect in major business achievements abroad. One problem to think is how long such a technological or product benefit will carry on. In history, a company with a competitive edge could calculate on being the only supplier to foreign markets for years to come. This kind of benefit, however, has shrunk dramatically because of competing technologies and a common lack of international patent protection (Porter, 2000). Many manufacturing business organizations are using information and communication technology (ICT) in there all supply chain management activities (Naude \& Badenhorst-Weiss, 2011a). ICT is the latest technological concept defined as an extensive method. (Yew Wong, Stentoft Arlbjørn, \& Johansen, 2005).

H5: Updated technology is positively related to operational efficiency

H6: Updated technology is negatively related to operational efficiency

\subsection{Management and culture}

Based on the type of business and the environment within it, different companies would have different forms of culture within their workplace. The culture would have direct connection with the processes and the stakeholders that the company is associated with (Maximini, 2015). When considering the management of an organization, the proper guidance and senior management 
consultancy is a vital element in operational efficiency (Flynn, Koufteros, \& Lu, 2016). As one of the major responsibilities of top management is to provide sufficient financial support and adequate resources for building a successful supply chain management system, the support of management will ensure that the organization has a high priority with required resources and attention (Africa, 2014). The lack of financial support and adequate resources will inevitably lead to failure. In addition to that primary support, there should be a directing committee, which can sponsor the money, ensure visibility and motivate the team (Simatupang, Wright, \& Sridharan, 2004).

The organizational culture relates to the situation and work environment that the managers and employees are associated with. The basic framework for organizational culture is the set of rules and regulations that are in place, and within this framework, the values, practices, and contribution of the staff shape up the culture (Homburg \& Pflesser, 2000). There are various elements such as business type, processes, demographics and attitudes of the staff contribute immensely to the culture. The "Corporate culture" is defined as mutual potentials, performs and objectives that are common through the mainstream of the group (Naude \& Badenhorst-Weiss, 2011b). The aspect of "Proper Management" is a serious factor for effective operational efficiency and productivity performance of the business (Chopra \& Meind1, 2007). Leadership management needs communal culture, privacy guard, responsibility, high management knowledge, good attitude and specialized, decisive in decision making and principles with constant performance measurement Naude \& Badenhorst-Weiss, 2011b). Similarly, the same authors stated that businesses have unsuitable or inadequate cultural basics are persuaded to be unsuccessful when approving operations management practices. As per Sohrabpour, Oghazi, and Olsson (2016) an effective supply chain is determined by organizational commitment and power.

H7: Management and culture is positively related to operational efficiency

H8: Management and culture is negatively related to operational efficiency

There are four categories of which are compulsory to accomplish high supply chain performance such as higher management support to departmental support, channel support and infrastructural support (Sohrabpour et al., 2016). 


\subsection{Supply chain management}

Cucchiella and Koh (2012) defined supply chain as an integration of complex tasks in getting and achieving customer satisfaction. Similarly, Cucchiella and Koh (2012) mentioned a supply chain as a network that supplies a specific product than raw material to finishing product. Ayers (2006) mentioned that the common objective of any supply chain activity as the achievement of efficiency. The conception of effectiveness as per (Naude \& Badenhorst-Weiss, 2011b) is an actor's capability to supply resolutions that offer price to marketplaces (customers). The supply chain practices are referring to complete group of activities which are completed in business organizations to improve the efficiency in the internal supply chain activities (Yew Wong et al., 2005). The present evaluation of the supply chain activities and practices that contains partnership with the supplier, procedure of outsourcing, compression of cycle time, continuous process flow and sharing or technology and information, purchasing the supply quality and relations, customer supply chain practices are defined as a set of activities conducted for an organization to promote effective management of its supply chain (Msimangira, 2003). A study by Joo, Messer Jr, and Bradshaw (2009) rated the suppliers influence as comparatively common measurable characteristic. An anonymous midsize manufacturing company in the aerospace industry has provided a full year of historical data on its 30 largest Tier 1 suppliers to aid this work. This study applies Data Envelopment Analysis (DEA) to the supplier data and results in the comparative rankings of supplier performance.

According to Reimann and Ketchen Jr (2017) supply chain practices refers to how business organizations utilize their organizational supplier processes, technology and capabilities to improve supply chain performance and organizational competitive advantage and how the manufacturing, logistic, materials, distribution and transportation functions are coordinated in organizations. This also includes supply chain practices and means which involved in business organizations planning and strategy for coordination of supply chain practices. The collaboration between business functions internally as well as across company is also a part of supply chain management practices (Reimann \& Ketchen Jr, 2017). Furthermore, based on the above extensive literature review a more concise framework is used to measure the operational efficiency of Apparel industry in emerging economies. 
H9: Supply chain management is positively related to operational efficiency

H10: Supply chain management is negatively related to operational efficiency

\section{Future research perspectives}

The present research focused on apparel sector. The same study can be conducted to other industries such as tea and rubber manufacturing sector. This study can expand by using the perspectives and viewpoints of employees, stakeholders including suppliers, buyers and customers in order to get a complete picture of the scenario. According to the literature review, one gap which is evident were that for future researchers less research on operational efficiency in apparel industry. Majority of those studies focused on the developed countries with less studies focusing the emerging countries. Majority of the existing studies used quantitative data collection methods such as surveys, questionnaires and few studies used qualitative or exploratory approaches with semi-structured interviews and open-ended surveys as the main data collection instruments. Furthermore, this is a cross-sectional case study and that a longitudinal study may enhance the understanding of trends over time with regard to operational efficiency in apparel industry which is another area for the future research.

\section{Conclusion}

As mentioned above, operational efficiency in emerging economies is an interesting research area. The main objective of this study is to develop a more consice conceptual frmawork which can be used to measure the operational efficiency of Apparel industry in emerging economies. This conceptual framework is based on an extensive literature review with fifty (50) research articles which assessed or discussed about the operational efficiency in Apparel sector of emerging economies. Four different databases been used to access the research articles, such as Sage, Google Scholar, Scopus, and Pro Quest in developing this conceptual framework. This conceptual framework consists of five independent variables which are labor productivity, inventory management, technology, organizations management, supply chain management and operational efficiency as the dependent variable. As a unique contribution this paper investigated five major factors which affects the operational efficiency in apparel sector of emerging economies. This will facilitate the future researchers as they can use this conceptual framework to measure the operational efficiency in apparel companies. This model has not previously used to evaluate the 
apparel sector thereby providing the future researchers to measure operational efficiency. The other theoretical implications are that more theoretical frameworks are necessary to evaluate operational efficiency. Based on the literature review it is evident that less research conducted on measuring the operational efficiency in apparel sector of emerging economies.

\section{Limitations}

There are certain limitations in this study. Study is limited towards the four databases which are Sage, Google Scholar, Scopus and Pro Quest in developing this conceptual framework. These variables were not tested due to the limited time constraints. It is argued to have limitations due to the lack of well-defined structure and protocols as this study is applicable for a cross sectional case study and not a longitudinal study (Yin, 1999). Therefore, the researcher mitigated this limitation by using the conceptual framework of developed using the literature review which provides a proper structure.

\section{References}

Aksezer, C. S., \& Benneyan, J. C. (2010). Assessing the efficiency of hospitals operating under a unique owner: a DEA application in the presence of missing data. International Journal of Services and Operations Management, 7(1), 53-75.

Arunkumar, O., \& Ramanan, T. R. (2017). Operational efficiency and its determinants of Indian food and beverages industries: a DEA approach. International Journal of Services and Operations Management, 27(1), 1-18.

Ayers, J. B. (2006). Handbook of supply chain management: Auerbach Publications.

Barnett, W. P., \& Burgelman, R. A. (1996). Evolutionary perspectives on strategy. Strategic Management Journal, 17(S1), 5-19.

Bergs, J. (2002). Effect of healthy workplaces on well-being and productivity of office workers.

Paper presented at the Proceedings of International Plants for People Symposium.

Bhattacharya, D., \& Rahman, M. (1999). Female Employment under Export-Propelled Industrialization: Prospects for Internalizing Global Opportunities in Bangladesh's Apparel Sector. Retrieved from

Cheng, Q., Goh, B. W., \& Kim, J. B. (2017). Internal control and operational efficiency. 
Chopra, S., \& Meindl, P. (2007). Supply chain management. Strategy, planning \& operation Das summa summarum des management (pp. 265-275): Springer.

Cucchiella, F., \& Koh, L. (2012). Green supply chain: how do carbon management and sustainable development create competitive advantage for the supply chain? Supply Chain Management: An International Journal, 17(1).

Deraniyagala, S. (2001). The impact of technology accumulation on technical efficiency: An analysis of the Sri Lankan clothing and agricultural machinery industries. Oxford Development Studies, 29(1), 101-114.

Dhaliwal, D., Hogan, C., Trezevant, R., \& Wilkins, M. (2011). Internal control disclosures, monitoring, and the cost of debt. The Accounting Review, 86(4), 1131-1156.

Embuldeniya, A. (2015). Impact of Apparel Industry on the Economy of Sri Lanka.

Feng, M., Li, C., McVay, S. E., \& Skaife, H. (2014). Does ineffective internal control over financial reporting affect a firm's operations? Evidence from firms' inventory management. The Accounting Review, 90(2), 529-557.

Fernie, J., \& Azuma, N. (2004). The changing nature of Japanese fashion: Can quick response improve supply chain efficiency? European Journal of Marketing, 38(7), 790-808.

Flynn, B. B., Koufteros, X., \& Lu, G. (2016). On theory in supply chain uncertainty and its implications for supply chain integration. Journal of Supply Chain Management, 52(3), $3-27$.

Gaither, N., \& Frazier, G. (2002). Operations management: South-Western/Thomson Learning.

Gereffi, G., \& Frederick, S. (2010). The global apparel value chain, trade and the crisis: challenges and opportunities for developing countries: The World Bank.

González, E., \& Álvarez, A. (2001). From efficiency measurement to efficiency improvement: The choice of a relevant benchmark. European Journal of Operational Research, 133(3), $512-520$.

Homburg, C., \& Pflesser, C. (2000). A multiple-layer model of market-oriented organizational culture: Measurement issues and performance outcomes. Journal of marketing research, 37(4), 449-462.

Hugos, M. H. (2018). Essentials of supply chain management: John Wiley \& Sons.

Hulten, C. R. (2001). Total factor productivity: a short biography New developments in productivity analysis (pp. 1-54): University of Chicago Press. 
Jacobs, F. R., Chase, R. B., \& Lummus, R. R. (2014). Operations and supply chain management: McGraw-Hill/Irwin New York, NY.

Jarkas, A. M., \& Bitar, C. G. (2011). Factors affecting construction labor productivity in Kuwait. Journal of construction engineering and management, 138(7), 811-820.

Joo, S.-J., Messer Jr, G. H., \& Bradshaw, R. (2009). The performance evaluation of existing suppliers using data envelopment analysis. International Journal of Services and Operations Management, 5(4), 429-443.

Joshi, R., \& Singh, S. (2010). Estimation of total factor productivity in the Indian garment industry. Journal of Fashion Marketing and Management: An International Journal, 14(1), 145-160.

Kalluru, S. R., \& Bhat, S. K. (2009). Determinants of cost efficiency of commercial banks in India. IUP Journal of Bank Management, 8(2), 32.

Keiser, S., Garner, M. B., \& Vandermar, D. (2017). Beyond design: The synergy of apparel product development: Bloomsbury Publishing USA.

Kim, J.-O., Traore, M., \& Warfield, C. (2006). The textile and apparel industry in developing countries. Textile progress, 38(3), 1-64.

Kotler, P., \& Armstrong, G. (2010). Principles of marketing: Pearson education.

Maximini, D. (2015). Organizational Culture Models The Scrum Culture (pp. 9-25): Springer.

Miller, D., \& Williams, P. (2009). What price a living wage? Implementation issues in the quest for decent wages in the global apparel sector. Global Social Policy, 9(1), 99-125.

Moodley, S. (2002). E-business in the South African apparel sector: a utopian vision of efficiency? The Developing Economies, 40(1), 67-100.

Moodley, S. (2003). The potential of internet-based business-to-business electronic commerce for a" technology follower": the case of the South African apparel sector. International Journal of Internet and Enterprise Management, 1(1), 75-95.

Moodley, S., \& Morris*, M. (2004). Does e-commerce fulfil its promise for developing country (South African) garment export producers? Oxford Development Studies, 32(2), 155-178.

Moore, M. (2002). Retail performance in US apparel supply chains: operational efficiency, marketing effectiveness and innovation. Journal of Textile and Apparel Technology and Management, 2(3), 1-9. 
Msimangira, K. A. (2003). Purchasing and supply chain management practices in Botswana. Supply Chain Management: An International Journal, 8(1), 7-11.

Naude, M. J., \& Badenhorst-Weiss, J. A. (2011a). The effect of problems on supply chain wide efficiency. Journal of Transport and Supply Chain Management, 5(1).

Naude, M. J., \& Badenhorst-Weiss, J. A. (2011b). The effect of problems on supply chain wide efficiency. Journal of Transport and Supply Chain Management, 5(1), 278-298.

Okwang'a, B. C., Mungania, A. K., \& Karanja, J. G. (2015). Analysis of Factors Affecting the Operational Efficiency of Jua Kali Sector: A Case of Apparel Industry in Nairobi, Kenya.

Porter, M. E. (2000). Location, competition, and economic development: Local clusters in a global economy. Economic development quarterly, 14(1), 15-34.

Ramaswamy, K., \& Gereffi, G. (1998). India's apparel sector in the global economy: Catching up or falling behind. Economic and Political Weekly, 122-130.

Reimann, F., \& Ketchen Jr, D. J. (2017). Power in supply chain management. Journal of Supply Chain Management, 53(2), 3-9.

Roberts, S., \& Thoburn, J. (2003). Adjusting to trade liberalisation: the case of firms in the South African textile sector. Journal of African Economies, 12(1), 74-103.

Sayer, A. A., Robinson, S. M., Patel, H. P., Shavlakadze, T., Cooper, C., \& Grounds, M. D. (2013). New horizons in the pathogenesis, diagnosis and management of sarcopenia. Age and ageing, 42(2), 145-150.

Scott, A. J. (2006). The changing global geography of low-technology, labor-intensive industry: clothing, footwear, and furniture. World Development, 34(9), 1517-1536.

Simatupang, T. M., Wright, A. C., \& Sridharan, R. (2004). Applying the theory of constraints to supply chain collaboration. Supply Chain Management: An International Journal, 9(1), 57-70.

Slack, N. (2015). Operations strategy: Wiley Online Library.

Slack, N., Brandon-Jones, A., \& Johnston, R. (2013). Prinípios de Administração da Produção’: Editoria Atlas.

Sohrabpour, V., Oghazi, P., \& Olsson, A. (2016). An improved supplier driven packaging design and development method for supply chain efficiency. Packaging Technology and Science, 29(3), 161-173.

Staiger, J. (2017). Offshore Outsourcing im Dienstleistungssektor. 
Stevenson, W. J., \& Hojati, M. (2007). Operations management (Vol. 8): McGraw-Hill/Irwin Boston.

Sufian, F. (2007). The efficiency of Islamic banking industry in Malaysia: Foreign vs domestic banks. Humanomics, 23(3), 174-192.

Tuuli, M. M., \& Rowlinson, S. (2010). An exploratory study of the contextual meaning and consequences of empowerment in project teams.

Yadlapalli, A., Rahman, S., \& Gunasekaran, A. (2018). Socially responsible governance mechanisms for manufacturing firms in apparel supply chains. International Journal of Production Economics, 196, 135-149.

Yew Wong, C., Stentoft Arlbjørn, J., \& Johansen, J. (2005). Supply chain management practices in toy supply chains. Supply Chain Management: An International Journal, 10(5), 367378.

Yin, R. K. (1999). Enhancing the quality of case studies in health services research. Health services research, 34(5 Pt 2), 1209. 